\title{
APLIKASI TEKNIK EVALUASI PADA MATA PELAJARAN AKIDAH AKHLAK DI MADRASAH ALIYAH NEGERI
}

\section{Herman Yunianto}

Universitas Islam Indonesia, Yogyakarta, Indonesia hermanyunian@gmail.com

\section{Nanang Nuryanta}

Universitas Islam Indonesia, Yogyakarta, Indonesia 954220101@uii.ac.id

DOI: 10.20885/tarbawi.vol13.iss1.art5

\begin{abstract}
The limited opportunity for teachers to apply evaluation on akidah akhlak subject in madrasah is one of the reasons this research was conducted. This study aims to determine the implementation of cognitive, affective, and psychomotor evaluation techniques on akidah akhlak subject s for class XI of the Religious Program in MAN 3 Sleman. This research use a qualitative approach; purposive and snowball sampling for determining data sources; observations, interviews, and documentation for collecting data; triangulation of sources, techniques, and time for testing the validity of the data; as well as data reduction, display data and conclusions drawing for analyzing data. The results showed that the techniques used in the evaluation of akidah akhlak subject were: (a) cognitive aspects including: written tests, oral tests, and assignments using multiple choice assessment instruments and descriptions, (b) the affective aspect uses observation techniques using a Likert scale, thrustone, guttman, and interest measurement, and (c) psychomotor aspects include: practical techniques and portfolios.
\end{abstract}

Keywords: Evaluation Technique; Akidah Akhlak Subject; Madrasah 


\title{
el-Tarbawj Herman Yunianto \& Nanang Nuryanta
}

\begin{abstract}
Abstrak
Terbatasnya kesempatan guru dalam menerapkan evaluasi dalam mata pelajaran akidah akhlak di madrasah menjadi salah satu alasan penelitian ini dilakukan. Penelitian ini bertujuan untuk mengetahui implementasi teknik evaluasi ranah kognitif, afektif, dan psikomotorik dalam pembelajaran akidah akhlak kelas XI Program Keagamaan di MAN 3 Sleman. Penelitian dengan pendekatan kualitatif; purposive dan snowball sampling dalam menentukan sumber data; obervasi, wawancara, dan dokumentasi dalam mengumpulkan data; triangulasi sumber, teknik, dan waktu dalam menguji keabsahan data; serta reduksi data, penyajian data dan pengambilan kesimpulan dalam menganalisis data. Hasil penelitian menunjukan bahwa teknik yang digunakan dalam evaluasi pembelajaran akidah akhlak yaitu: (a) aspek kognitif meliputi: tes tertulis, tes lisan, dan penugasan dengan menggunakan instrument penilaian pilihan ganda dan uraian. (b) aspek afektif menggunakan teknik observasi dengan menggunakan skala likert, thrustone, guttman, dan pengukuran minat. (c) aspek psikomotorik meliputi: teknik praktik dan portofolio.
\end{abstract}

Kata Kunci: Teknik Evaluasi; Mata Pelajaran Akidah Akhlak; Madrasah

\section{Pendahuluan}

Dari sudut pandang profesionalisme seorang pendidik, kegiatan evaluasi adalah tugas yang melekat pada pendidik profesional. Seorang pendidik profesional selalu menginginkan umpan balik tentang program pendidikan yang telah dilakukannya. Melalui evaluasi yang dilakukan secara sistematis akan diketahui sejauh mana tujuan pembelajaran telah tercapai. Evaluasi bukan hanya kumpulan teknik, tetapi evaluasi adalah proses berkelanjutan yang mendasari keseluruhan kegiatan belajar mengajar untuk mewujudkan proses belajar mengajar yang efektif. Sesuai dengan prinsip pembelajaran yang menyatakan bahwa belajar adalah proses perubahan perilaku pada siswa, evaluasi pendidikan dapat secara otomatis digunakan 
sebagai alat untuk mengetahui perubahan tersebut. Ini berarti bahwa dalam proses belajar mengajar harus ada kriteria tertentu yang dapat digunakan sebagai tolok ukur untuk pelaksanaan evaluasi (Suadinmath, 2019).

Dalam Petunjuk Teknis Evaluasi Hasil Belajar pada Madrasah Aliyah Dirjen Pendis tahun 2018, ada dua jenis acuan penilaian yang dipakai dalam mengelompokan peserta didik yaitu: (1) Penilaian Acuan Norma (PAN), Penilaian Acuan Norma ialah penilaian yang membandingkan hasil belajar setiap peserta didik terhadap hasil dalam kelompoknya. PAN digunakan untuk menentukan status setiap peserta didik terhadap kemampuan peserta didik lainnya. Artinya, PAN digunakan apabila ingin mengetahui kemampuan peserta didik di dalam komunitasnya seperti di kelas, madrasah, dan lain sebagainya. Nilai hasil dari PAN tidak mencerminkan tingkat kemampuan dan penguasaan peserta didik tentang materi pembelajaran yang diujikan, tetapi hanya menunjukan posisi peserta didik dalam kelompoknya. Misalnya kelompok cepat, sedang atau lambat. Hasil PAN digunakan oleh guru dan madrasah untuk memonitor perkembangan individu peserta didik dan tidak harus dipublikasikan. (2) Penilaian Acuan Kriteria (PAK), Penilaian acuan kriteria (PAK) adalah pengukuran keberhasilan peserta didik dengan menggunakan kriteria tertentu yang telah ditetapkan. Dengan PAK setiap peserta didik dapat diketahui apa yang telah dan belum dikuasainya. Melalui penilaian ini kita dapat mengembangkan alat ukur berhasil atau tidak suatu proses pembelajaran dengan cara mengadakan tes diawal pembelajaran (pretest) dan tes pada akhir pembelajaran (postest). Dari hasil perbandingan kedua tes tersebut akan diketahui seberapa besar materi yang bisa diterima peserta didik dalam kegiatan pembelajaran.

Sesuai dengan petunjuk teknis evaluasi (2018), dalam melakukan evaluasi harus memuat beberapa prinsip evaluasi hasil 


\section{el-Tarbawj Herman Yunianto \& Nanang Nuryanta}

belajar, yaitu (1) sahih, artinya evaluasi didasarkan pada data yang mencerminkan kemampuan yang diukur, (2) objektif, artinya evaluasi didasarkan pada prosedur dan kriteria yang jelas, tidak dipengaruhi subyektivitas evaluator, (3) adil, berarti evaluasi tidak menguntungkan atau merugikan peserta didik, (4) terpadu, berarti evaluasi oleh pendidik merupakan salah satu komponen yang tak terpisahkan dari kegiatan pembelajaran, (5) terbuka, berarti prosedur evaluasi, kriteria evaluasi, dan dasar pengambilan keputusan dapat diketahui oleh pihak yang berkepentingan, (6) menyeluruh dan berkesinambungan, berarti evaluasi oleh pendidik mencakup semua aspek kompetensi dengan menggunakan berbagai teknik penilaian yang sesuai, (7) sistematis, berarti evaluasi dilakukan secara berencana dan bertahap dengan mengikuti langkah-langkah yang baku, (8) beracuan kriteria, berarti evaluasi didasarkan pada ukuran pencapaian kompetensi yang ditetapkan, (9) akuntabel, berarti evaluasi dapat dipertanggungjawabkan, baik dari segi teknik, prosedur, maupun hasilnya.

Penilaian aspek pengetahuan dilakukan melalui tahapan: menyusun perencanaan penilaian, mengembangkan instrumen penilaian, melaksanakan penilaian memanfaatkan hasil penilaian, melaporkan hasil penilaian dalam bentuk angka dengan skala 0-100 dan deskripsi. Prosedur penilaian aspek sikap dilakukan melalui tahapan: mengamati perilaku peserta didik selama pembelajaran, mencatat perilaku peserta didik dengan menggunakan lembar observasi/pengamatan, menindaklanjuti hasil pengamatan, dan mendeskripsikan perilaku peserta didik. Dan Penilaian aspek keterampilan dilakukan melalui tahapan: menyusun perencanaan penilaian, mengembangkan instrumen penilaian, melaksanakan penilaian, memanfaatkan hasil penilaian, melaporkan hasil penilaian dalam bentuk angka dengan skala 0-100 dan deskripsi (Diktis, 2018). 
Untuk teknik evaluasi ranah kognitif menggunakan tes tertulis (benar-salah, pilihan ganda, isian, jawaban singkat, menjodohkan, dan uraian), tes lisan (kuis dan tanya jawab), dan penugasan (tugas yang dilakukan secara individu atau kelompok di madrasah dan/atau di luar madrasah, baik secara formal maunun informal). Sedangkan pada ranah evaluasi teknik yang digunakan adalah observasi, dimana sikap peserta didik diamati secara berkesinambungan. Bagian ini yang dicatat adalah perilaku peserta didik yang paling positif (baik) dan paling negatif (kurang baik). Sedangkan untuk penilaian ranah psikomotorik dengan praktik, proyek, portofolio, dan produk (Diktis, 2018).

MAN 3 Sleman adalah sekolah yang akan dijadikan sebagai tempat penelitian. Dalam penelitian kali ini peneliti lebih fokus pada teknik evaluasi yang digunakan dalam pembelajaran akidah ahklak kelas XI Program Keagamaan. Evaluasi dilakukan dengan beberapa tahap yaitu menyusun perencanaan, mengembangkan instrument penilaian, meaksanakan penilaian, dan melaporkan hasil. Sebelum melakukan evaluasi, pendidik juga menyusun evaluasi hasil belajar melalui rpp dan silabus dan sekolah juga sudah menetapkan kkm berdasarkan kesepakatan rapat dewan pendidik. Evaluasi dilakukan dalam 3 aspek, yaitu aspek pengetahuan (kognitif), aspek sikap (afektif), dan aspek keterampilan (psikomotorik). Untuk aspek pengetahuan (kognitif) evaluasi dilakukan menggunakan teknik: tes pilihan ganda dan uraian. Untuk aspek sikap (afektif) evaluasi dilakukan dengan cara pengamatan secara langsung oleh pendidik kemudian mencatat perilaku peserta didik menggunakan lembar observasi atau pengamatan yang menggunakan teknik skala likert, thrustone, guttman, dan pengukuran minat. Sedangkan untuk aspek keterampilan (psikomotorik) evaluasi dilakukan menggunakan teknik pratik. 


\section{el-Tarbawj Herman Yunianto \& Nanang Nuryanta}

Dari hasil observasi peneliti, terdapat beberapa kekurangan dalam pelaksanaan evaluasi yang dilakukan oleh guru akidah akhklak kelas XI Program Keagamaan di MAN 3 Sleman, misalnya dari ranah kognitif teknik yang digunakan dalam melakukan evaluasi hanya menggunakan teknik tes pilihan ganda dan uraian, tes lisan, dan penugasan. Menurut petunjuk teknis evaluasi hasil belajar pada madrasah Aliyah yang dikeluarkan oleh DIRJEN Pendidikan Islam no 3752 tahun 2018 menyebut teknik evaluasi ranah kognitif: tes pilihan ganda, benar-salah, isian, jawaban singkat, menjodohkan, uraian, lisan, dan penugasan. Sedangkan untuk ranah afektif teknik yang digunakan adalah: skala likert, thrustone, guttman, dan pengukuran minat dari enam skala teknik evaluasi ranah afektif, dua teknik yang belum digunakan adalah skala pilihan ganda dan semantic differential. Untuk ranah psikomotorik teknik yang digunakan adalah teknik praktik dan portofolio. Menurut petunjuk teknis evaluasi hasil belajar pada madrasah Aliyah yang dikeluarkan oleh DIRJEN Pendidikan Islam no 3752 tahun 2018 menyebutkan teknik yang digunakan dalam evaluasi ranah psikomotorik adalah teknik praktik, portofolio, proyek, dan produk. Jadi peneliti menyimpulkan bahwa tidak semua teknik evaluasi diterapkan dalam evaluasi pembelajaran akidah akhlak kelas XI Program Keagamaan di MAN 3 Sleman.

Berdasarkan hasil observasi di madrasah terkait, dari penerapan evaluasi aspek kognitif, afektif, dan psikomotorik tersebut peneliti menemukan informasi bahwa peserta didik lebih berminat pada evaluasi ranah kognitif dan psikomotorik. Padahal seharusnya dalam pembelajaran akidah akhlak aspek yang sangat penting adalah pada ranah afektif, karena tujuan pembelajaran akidah akhlak adalah menjadikan siswa berakhlak yang baik menurut ajaran agama Islam. Oleh karena itu, peneliti menyimpulkan bahwa evaluasi yang dilakukan di MAN 3 Sleman khususnya pada pembelajaran akidah akhlak kenapa beberapa teknik evaluasi belum diterapkan karena: (1) 
keterbatasan guru dalam mengatur waktu yang terbatas. Hal ini didasarkan pada fakta bahwa jam pembelajaran akidah akhlak hanya dua jam pelajaran/minggu. (2) Keadaan siswa yang belum tentu fit pada saat evaluasi dilaksanakan. (3) Kemampuan siswa yang berbeda dalam menangkap pelajaran di kelas. (4) kemampuan siswa yang berbeda untuk mengekspresikan pemikiran dan pemahamannya.

Adapun alasan peneliti memilih MAN 3 Sleman sebagai lokasi penelitian karena MAN 3 Sleman termasuk madrasah berprestasi berdasarkan data yang diambil dari website madrasah (perpustakaan terbaik nasional, sekolah sehat nasional, adiwiyata nasioanal). Selain itu MAN 3 Sleman juga menjadi MAN model untuk tingkat nasional (juara dua olimiade matematika, juara dua kompetisi sains maple fisika dan ekonomi, juara dua band religi, juara tiga AKSIOMA tenis meja) dan bahkan sudah berprestasi internasional (kerjasama dengan sekolah di Singapura, Malaysia, dan Thailand). Berdasarkan beberapa alasan tersebut maka peneliti memiliki asumsi bahwa madrasah ini memiliki keunggulan dan keunikan untuk dijadikan sebagai lokasi penelitian. Sehingga peneliti menentukan judul penelitian adalah "Implementasi Teknik Evaluasi Ranah Kognitif, Afektif, dan Psikomotorik Pada Pembelajaran Akidah Akhlak Kelas XI Program Keagamaan di MAN 3 Sleman".

Berikut merupakan penelitian terbaru terkait yaitu penelitian yang dilakukan Iin Nurbudiyani (2013) dengan judul "Pelaksanaan Pengukuran Ranah Kognitif, Afektif, dan Psikomotorik pada Pelajaran IPS Kelas III SD Muhammadiyah Palangkaraya". Hasil penelitian menunjukkan bahwa evaluasi harus dilakukan dalam proses pembelajaran guna mendapatkan data kemajuan peserta didik, di sisi lain guru juga dapat mengamati kemajuan tersebut sesuai atau tidak dengan tujuan pembelajaran. Bahwa evaluasi harus menggambarkan ranah kognitif, afektif dan psikomotor. Dalam mengukur ranah kognitif guru menggunakan tes pilihan ganda, dan dalam mengukur 


\section{el-Tarbawj Herman Yunianto \& Nanang Nuryanta}

ranah afektif dan psikomotorik guru menggunakan lembar observasi. Selanjutnya penelitian skripsi oleh Siti Ramadhana Fitriani (2017) dengan judul "Pelaksanaan Evaluasi Pembelajaran Akidah Akhlak di MAN 2 Kandangan kabupaten Hulu Sungai Selatan" menyatakan bahwa implementasi evaluasi pada mata pelajaran akidah akhlak belum maksimal dikarenakan pengalaman guru yang masih rendah serta penguasaan materi evaluasi yang belum cukup sehingga guru kesulitan menyesuaikan rencana evaluasi dengan pelaksanaannya. Disamping itu jumlah peserta didik dengan jumlah mata pelajaran yang menghambat guru untuk dapat mengimplementasikan evaluasi pembelajaran. Hal yang ditemukan dari penelitian ini juga menunjukkan bahwa guru belum mendapatkan bimbingan dari kepala sekolah.

Dari penelitian yang telah dipaparkan sebelumnya, dapat dipahami bahwa telah dilakukan diberbagai daerah. Namun fokus penelitian ini terletak pada teknik evaluasi yang digunakan guru dalam pembelajaran akidah akhlak yang fokus pada kelas program keagamaan. Kegunaan penelitian ini adalah sebagai bahan ilmu pengetahuan dan wawasan khususnya yang berkaitan dengan teknik evaluasi ranah kognitif, afektif, dan psikomotorik dan pengembangannya di sekolah serta penelitian ini berguna sebagai bahan referensi dan masukan khususnya bagi guru dan sekolah yang menyangkut teknik evaluasi ranah kognitif, afektif, dan psikomotorik pada mata pelajaran akidah akhlak. Selanjutnya penelitian ini bertujuan untuk mengetahui implementasi teknik evaluasi ranah kognitif, afektif, dan psikomotorik dalam pembelajaran akidah akhlak kelas XI Program Keagamaan di MAN 3 Sleman. 


\section{Metode Penelitian}

Jenis penelitian yang digunakan peneliti adalah penelitian lapangan dan menggunakan pendekatan kualitatif. Istilah penelitian kualitatif adalah jenis penelitian yang temuan-temuannya tidak diperoleh melalui prosedur statistik atau bentuk hitungan lainnya (Sugiyono, 2013). Penelitian ini termasuk pada metode penelitian naturalistic karena penelitian dilakukan dalam kondisi alamiah (natural setting); pada sisi lain juga disebut sebagai metode etnografi karena penelitian dilakukan pada bidang antropologi budaya; dan juga disebut sebagai metode kualitatif karena data yang terkumpul bersifat kualitatif (Sugiyono, 2012).

Lokasi penelitian akan dilaksanakan di MAN 3 Sleman yang beralamat Jl. Magelang No. Km 4, Kutu Dukuh, Sinduadi, Mlati, Kabupaten Sleman, Daerah Istimewa Yogyakarta. Subyek dalam penelitian ini adalah sebagai berikut: (a) Waka Kurikulum MAN 3 Sleman, (b) Guru mata pelajaran Akidah Akhlak, dan (c) Siswa kelas XI Program Keagamaan sebanyak tiga orang siswa.

Teknik penentuan informan yang digunakan peneliti adalah purposive sampling dan snowball sampling. Purposive sampling adalah teknik pengambilan sampel sumber data dengan pertimbangan tertentu. Snowball sampling adalah teknik dalam mengambil data dengan mengambil sumber data sedikit kemudian bertambah semakin banyak sesuai kebutuhan. Hal tersebut dilakukan guna mendapatkan data yang lengkap (Sugiyono, 2015). Untuk memperoleh data yang diperlukan oleh peneliti, maka peneliti menggunakan teknik pengumpulan data sebagai berikut observasi, wawancara, dan dokumentasi. Sedangkan dalam menguji keabsahan data, peneliti menggunakan triangulasi sumber, triangulasi teknik, dan triangulasi waktu (Sugiyono, 2012). Dalam menganalisis data, peneliti pertama mereduksi data, lalu data yang sudah terpilih disajikan (penyajian 


\section{el-Tarbawj Herman Yunianto \& Nanang Nuryanta}

data), yang terakhir adalah menggambarkan kesimpulan (conclusion drawing) (Sugiyono, 2012).

\section{Hasil dan Pembahasan}

\section{Teknik Evaluasi Ranah Kognitif Pembelajaran Akidah Akhlak}

Berdasarkan wawancara yang dilakukan oleh peneliti dengan guru akidah akhlak kelas XI Program Keagamaan, beliau menyampaikan bahawa untuk melakukan evaluasi ranah kognitif sebelumnya harus menyusun terlebih dahulu perencanaan evaluasi yaitu melalui RPP (Rencana Pelaksanaan Pembelajaran). Didalam didalam RPP tersebut menjabarkan rancangan evaluasi yang akan dilaksanakan oleh guru akidah akhlak. Rancangannya berupa evaluasi dilakukan diranah kognitif, afektif, dan psikomotorik. Dan bentuk evaluasinya berupa tes tertulis, lisan, dan penugasan.

Terkait teknik evaluasi ranah kognitif yang digunakan, berikut pernyataan dari guru akidah akhlak kelas XI Program Keagamaan:

"Untuk instrument evaluasi aspek kognitif guru akidah akhlak di MAN 3 Sleman menggunakan bentuk evaluasi tes tertulis baik itu pilihan ganda maupun uraian, tes lisan, dan penugasan dengan instrument penilaian disesuaikan materi pembelajaran. Instrumen ini disusun sendiri oleh guru akidah akhlak".

Jika ditemukan ada siswa yang nilainya kurang dari kkm, maka dilakukan remidi atau pengayaan. Berikut wawancara peneliti dengan guru akidah akhlak kelas XI Program Keagamaan:

"Karenanya dari hasil evaluasi yang telah didapatkan, guru dapat membuat proses tindak lanjutnya, baik itu untuk meremidi bagi siswa yang belum tuntas maupun memberikan pengayaan bagi siswa yang sudah tuntas. Dengan demikian diharapkan seluruh siswa pada akhirnya bisa tuntas di setiap KD-nya. Dengan proses evaluasi pembelajaran yang demikian diharapkan mutu pembelajaran akidah akhlak dapat semakin baik meningkat 
dari waktu ke waktu, karena tingkat kemajuan anak bisa terpantau di setiap KD-nya"

\section{Teknik Evaluasi Ranah Afektif Pembelajaran Akidah Akhlak}

Kesuksesan evaluasi ranah afektif berimplikasi terhadap pencapaian evaluasi ranah afektif pula. Contohnya, guru yang mahir menggunakan strategi pembelajaran dengan keselarasan pada isi materi dan pesan moral dalam materi yang dibawakan, dapat berpengaruh positif pada ranah afektif peserta didik. Namun dalam proses penilaian ranah afektif berbeda dengan ranah kognitif dalam hal waktu. Pengukuran ranah afektif tidak dapat dilakukan setiap waktu karena perubahan perilaku dalam diri peserta didik.

Setelah perencanaan evaluasi disusun dalam RPP selanjutnya menentukan teknik evaluasi yang digunakan. Dalam pelaksanaan evaluasi ranah afektif di MAN 3 Sleman teknik evaluasi yang digunakan oleh guru akidah akhlak kelas XI Program Keagamaan adalah berupa observasi/pengamatan dan penilaian teman sebaya. Berikut hasil wawancara peneliti dengan guru akidah akhlak kelas XI Program Keagamaan terkait teknik evaluasi ranah afektif:

"Alat instrument aspek afektif pada mata pelajaran akidah akhlak di MAN 3 Sleman guru menggunakan tabel penilaian yang disesuaikan antara materi pembelajaran yang akan disampaikan dengan aspek afektif yang akan dinilai. Sedangkan untuk penilaiannya guru menggunakan observasi/pengamatan dan penilaian teman sebaya".

Berikut hasil wawancara peneliti dengan salah satu siswa kelas XI Program Keagamaan: "Untuk teknik evaluasi guru biasanya mengamati berbagai sikap dan tindakan dari siswa-siswi".

Dari penjelasan di atas dapat disimpulkan bahwa evaluasi yang dilaksanakan oleh guru akidah akhlak kelas XI Program Keagamaan pada ranah afektif sudah baik karena mengacu pada surat keputusan 


\section{el-Tarbawj Herman Yunianto \& Nanang Nuryanta}

yang telah dibuat oleh Dirjen Pendidikan Islam No.3571 tahun 2019 tentang petunjuk teknis penilaian hasil belajar pada madrasah Aliyah.

\section{Teknik Evaluasi Ranah Psikomotorik Pembelajaran Akidah} Akhlak

Penampilan dan attitude menjari kawasan pengukuran ranah psikomotorik. Secara umum, proses penilaian dimulai dari pengukuran ranah kognitif kemudian psikomotor-nya. Misal, penampilan peserta didik dinilai berdasarkan pengetahuan akhlak terpuji dalam berpakaian, selanjutnya bagaimana cerminan keseharian peserta didik dalam berpakaian. Proses itulah yang disebut sebagai evaluasi ranah psikomotorik (Arikunto, 2006).

Dari hasil wawancara peneliti dengan guru akidah akhlak kelas XI Program Keagamaan menyebutkan bahwa pengukuran ranah psikomotorik dilakukan dengan keberhasilan pembelajaran sebelumnya sebagai tolak ukur. Dari hasil evaluasi sebelumnya, guru dapat memberikan tindak lanjut berupa remidi bagi peserta didik yang belum tuntas dan pengayaan bagi peserta didik yang sudah tuntas. Hal tersebut dilakukan dengan harapan bahwa seluruh peserta didik tuntas di setiap Kompetensi Dasar (KD). Dengan begitu, mutu pembelajaran akidah akhlak dapat terpantau dengan baik dan bahkan dapat meningkat.

Untuk teknik evaluasi ranah psikomotorik yang digunakan oleh guru akidah akhlak kelas XI Program Keagamaan adalah:

"Sedangkan untuk penilaian aspek psikomotorik, dalam hal ini ranah KI-4, guru biasanya menyesuaikan dengan materi yang disampaikan. Untuk materi-materi yang memungkinkan siswa untuk unjuk diri biasanya guru menggunakan hafalan. Untuk materi-materi yang memungkinkan siswa untuk diskusi biasanya guru menggunakan pengamatan kemampuan siswa selama proses diskusi, baik itu ketika menyampaikan materi diskusi, menyampaikan pertanyaan maupun ketika menjawab pertanyaan". 
Salah satu siswa kelas XI Program Keagamaan juga mengungkap teknik evaluasi yang digunakan guru kelas XI Program Keagamaan: "Untuk teknik evaluasi ranah psikomoorik guru biasanya berdiskusi antar siswa, presentasi individu atau kelompok".

Dari penjelasan diatas dapat disimpulkan bahwa untuk melakukan evaluasi ranah psikomotorik dilakukan tergantung pada materi yang sesuai dengan aspek psikomotorik, jadi tidak semua materi pelajaran bisa diterapkan evaluasi ranah psikomotorik. Untuk teknik yang digunakan dalam evaluasi ranah kognitif oleh guru kelas XI Program keagamaan MAN 3 Sleman adalah melalui pengamatan praktik. Dalam hal ini guru memberikan contoh saat siswa berdiskusi guru tersebut mengamati siswa-siswanya yang presentasi dan juga yang aktif menanggapi dan bertanya saat diskusi dikelas. Tujuannya adalah melatih siswa menjadi lebih berani berbicara di depan orang banyak dan berpendapat didepan orang banyak.

\section{Kesimpulan}

Teknik yang digunakan dalam evaluasi pembelajaran akidah akhlak yaitu: (a) aspek kognitif meliputi: tes tertulis, tes lisan, dan penugasan dengan menggunakan instrument penilaian pilihan ganda dan uraian. (b) aspek afektif menggunakan teknik observasi dengan menggunakan skala likert, thrustone, guttman, dan pengukuran minat. (c) aspek psikomotorik meliputi: teknik praktik dan portofolio.

\section{Daftar Pustaka}

Ahmad Saifulloh \& Imam Safi'I. (2017). “Evaluasi Pembelajaran Mata Pelajaran Pendidikan Agama Islam di Sekolah Menengah Pertama (Studi Kasus di SMPN 2 Ponorogo)". Jurnal. Vol. 1. No. 1. 


\section{el-Tarbawj Herman Yunianto \& Nanang Nuryanta}

Ahmad Syaiful Ulum. (2017). “Implementasi Evaluasi Pembelajaran Pendidikan Agama Islam Berbasis Computer Base Test (Studi Mutisitus di SMA Negeri 2 Malang dan SMK PGRI Malang)". Tesis. Malang: UIN Maulana Malik Ibrahim Malang.

Arifin, Zaenal. (2009). Evaluasi Pembelajaran. Cet. 1. Bandung: PT Remaja Rosdakarya.

Arikunto, Suharsimi. (2006). Dasar-Dasar Evaluasi Pendidikan. Jakarta: Bumi Aksara

Burhan Baharun. (2016). " Penilaian Berbasis Kelas pada Pembelajaran Pendidikan Agama Islam di Madrasah". Jurnal Program Studi PGMI. Vol. 3. No. 2.

Cici Wahyuni. (2017). “Evaluasi Pembelajaran Akidah Akhlak Di MA Raudlatul Huda Ya Bakki Adipala Welahan Wetan". Skripsi. Purwokerto: UM Purwokerto.

Dahlan, Zaini. (2014). Qur'an Karim dan Terjemahan Artinya. Yogyakarta: UII Press.

Departemen Agam RI. (2004). “Pedoman Khusus Pengembangan Silabus dan Sistem Penilaian Aqidah dan Akhlak Madrasah Aliyah". Jakarta: Direktorat Jenderal Kelembagaan Agama Islam.

DIRJEN Pendidikan Islam No 3751, (2018). "Petunjuk Teknis Evaluasi Hasil Belajar Pada Madrasah Aliyah"

Fuad Ihsan, H. (2013). Dasar-Dasar Kependidikan. Jakarta: PT Raneka Cipta.

Ido Prijani Hadi. (2011). "Penelitian Khalayak Dalam Persoektif Reception Analysis". Jurnal Ilmiah SCRIPTURA, Vol. 2, No. 1.

Iin Nurbudiyani. (2013). "Pelaksanaan Pengukuran Ranah Kognitif, Afektif, dan Psikomotorik Pada Mata Pelajaran IPS". Anterior Jurnal. Vol. 13. No. 1.

Lilik Maftuhatin. (2014). “Evaluasi Pembelajaran Anak Berkebutuhan Khusus (ABK) Di Kelas Inklusif Di SD Plus Darul Ulum Jombang". Jurnal Studi Islam. Vol. 5. No 2.

Majid, Abdul M. (2009). Perencanaan Pembelajaran. Bandung: PT Remaja Rosdakarya. 
MAN 3 Sleman. Prestasi MAN 3 Sleman. Dikutip dari https://mayoga.sch.id. Tanggal 16 Oktober 2019.

M. Abdul Ghafur. (2008). “Implementasi Evaluasi Ranah Afektif untuk Pembelajaran Akidah Akhlak Di MA NU Nurul Huda Mangkang Tugu Semarang". Skripsi. Semarang: IAIN Walisongo.

M. Hidayat Ginanjar. (2017). "Pembelajaran Akidah Akhlak dan Korelasinya Dengan Peningkatan Akhlak Al-Karimah Peserta Didik". Jurnal Edukasi Islam. Vol. VI. No. 12.

Nata, Abuddin H. (2010). Ilmu Pendidikan Islam. Jakarta: Kencana Prenada Media Group.

Nunung Nuriyah. (2014). “Evaluasi Pembelajaran". Jurnal Edueksos. Vol. III. No. 1.

Nurgiyantoro, Burhan. (2009). Penilaian dalam Pengajaran Bahasa dan Sastra. Yogyakarta: BPFE-Yogyakarta.

Nurul Hidayah. (2014). "Implementasi Evaluasi Ranah Afektif Mata Pelajaran PAI DI SD AL Irsyad AL Islammiyah 02 Purwokerto". Skripsi. Purwokerto: STAIN Purwokerto.

PERMENDIKBUD RI No 22. (2016). "Standar Penilaian Pendidikan". Jakarta: Direktorat Jenderal Peraturan Perundangundangan Kementrian HAM.

Purwanto, Ngalim M. (1984). Prinsip-Prinsip Dan Teknik Evaluasi Pembelajaran. Bandung: PT Remaja Rosdakarya.

Reni Ratna Sari. (2018). "Pelaksanaan Evaluasi Pembelajaran Mata Pelajaran SKI Di MTsN Lampung tahun ajaran 2017/2018". Skripsi. Lampung: UIN Raden Intan Lampung.

Siti Ramadhana Fitriani. (2017). "Pelaksanaan Evaluasi Pembelajaran Akidah Akhlak Di MAN 2 Kandangan kabupaten Hulu Sungai Selatan". Skripsi. Banjarmasin: IAIN Antasi Banjarmasin.

Suadinmath. Melaksanakan Evaluasi Pendidikan Dengan Baik dan Benar. Dikutip dari http://suaidinmath.wordpress.com/2014/12/23/melaksanakanevaluasipendidikan-dengan-baik-dan-benar/tanggal 25 April 2019

Syahri Ramadhan. (2017). “Evaluasi Pendidikan Agama Islam di MTs Ibnul Qayyim Putri Yogyakarta”. Jurnal Al-Tariqah. Vol. 2. No. 1.

Sudijono, Anas. (2005). Pengantar Evaluasi Pendidikan. Jakarta: PT Rajagrafindo Persada. 


\section{el-Tarbawj Herman Yunianto \& Nanang Nuryanta}

Sudjana, Nana. (2005). Penilaian Hasil Proses Belajar Mengajar. Bansung: PT Remaja Rosdakarya.

(2019). Prinsip-Prinsip Dan Teknik Evaluasi Pembelajaran. Bandung: PT Remaja Rosdakarya.

Sugiyono. 2012. Memahami Penelitian Kualitatif. Cet. 7. Bandung: Alfabeta. . (2015). Metode Penelitian Pendidikan: Pendekatan Kuantitatif Kualitatif, dan RED. Bandung: Alfabeta. - (2008). Metode Penelitian Kuantitatif, Kualitatif dan RED. Bandung: $\quad$ Alfabeta. . (2013). Metode Penelitian Pendidikan. Bandung: Alfabeta.

Sukardi, M. (2008). Evaluasi Pendidikan Prinsip dan Operasionalnya. Jakarta: Bumi Aksara.

Sutomo. (1985). Teknik Penilaian Pendidikan. Surabaya: PT Bina Ilmu. 